\title{
$\alpha$-hederin induces autophagic cell death in colorectal cancer cells through reactive oxygen species dependent AMPK/mTOR signaling pathway activation
}

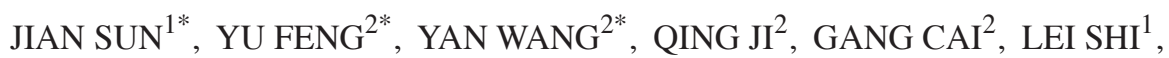 \\ YIYI WANG ${ }^{1}$, YAN HUANG ${ }^{1}$, JUE ZHANG ${ }^{1}$ and $\mathrm{QI} \mathrm{LI}^{2}$ \\ Departments of ${ }^{1}$ Clinical Laboratory and ${ }^{2}$ Medical Oncology, Shuguang Hospital, \\ Shanghai University of Traditional Chinese Medicine, Shanghai 201203, P.R. China
}

Received October 12, 2018; Accepted February 8, 2019

DOI: $10.3892 /$ ijo.2019.4757

\begin{abstract}
. $\alpha$-hederin, a monodesmosidic triterpenoid saponin, had previously demonstrated strong anticancer effects. In the current study, the pharmacological mechanism of autophagic cell death induced by $\alpha$-hederin was investigated in human colorectal cancer cells. First, through cell counting kit- 8 and colony formation assays, it was demonstrated that $\alpha$-hederin could inhibit the proliferation of HCT116 and HCT8 cell. Results of flow cytometry using fluorescein isothiocyanate Annexin V/propidium iodide and Hoechst 33258 staining indicated that $\alpha$-hederin could induce apoptosis. Western blotting demonstrated that $\alpha$-hederin could activate mitochondrial apoptosis signal pathway. Then, using light chain 3 lentiviral and electron microscope assay, it was demonstrated that $\alpha$-hederin could induce autophagy in colorectal cancer cells. In addition, immunohistochemistry results from in vivo experiments also demonstrated that $\alpha$-hederin could induce autophagy. AMP-activated protein kinase (AMPK)/mechanistic target of rapamycin (mTOR) signaling was demonstrated to be activated by $\alpha$-hederin, which could be blocked by reactive oxygen species (ROS) inhibitor NAC. Furthermore, NAC could inhibit apoptosis and autophagy induced by $\alpha$-hederin. Finally, 3-MA (autophagy inhibitor) reduced the inhibition of $\alpha$-hederin on cell activity, but it had no significant effect on apoptosis. In conclusion, $\alpha$-hederin triggered apoptosis through ROS-activated mitochondrial signaling pathway and
\end{abstract}

Correspondence to: Professor Qi Li, Department of Medical Oncology, Shuguang Hospital, Shanghai University of Traditional Chinese Medicine, 528 Zhangheng Road, Shanghai 201203, P.R. China E-mail: zhangjue425@hotmail.com

*Contributed equally

Key words: colorectal cancer, $\alpha$-hederin, autophagy, reactive oxygen species, AMP-activated protein kinase/mechanistic target of rapamycin signaling autophagic cell death through ROS dependent AMPK/mTOR signaling pathway activation in colorectal cancer cells.

\section{Introduction}

With $\sim 1.4$ million new cases every year worldwide, colorectal cancer is the third most common type of cancer with high incidence and mortality rates $(1,2)$. Currently, surgery with chemotherapy is the main treatment for colorectal cancer, but the 5-year survival rate of patients with colorectal cancer remains low (3). Therefore, identifying novel anticancer drugs is necessary.

An effective treatment strategy for colorectal cancer is to induce cell death (4). A number of studies have demonstrated that cell death mainly includes four major morphologically processes: Necrosis, apoptosis, autophagy and pyroptosis $(5,6)$. Autophagy is an important process in evolutionarily conserving cellular material and energy flow. It is a normal physiological process of metabolizing cellular material in evolved eukaryotic organisms and is one form of type II programmed cell death $(7,8)$. Autophagy enables cells to resist metabolic stress caused by the lack of nutrition and excessive proliferation of cells, and may promote the survival of tumor cells. For example, autophagy is an important cause of drug resistance in cancer cells during chemotherapy. However, excessive autophagy may lead to autophagic cell death (9). Therefore, the degree of autophagy determines whether the cell survives or dies.

Autophagy and apoptosis are both important mechanisms determining the survival or death of cancer cells. Cross-talk of autophagy and apoptosis has been documented in the tumorigenesis and progression of cancer (10), while the interplay between the two pathways in colorectal cancer has not yet been comprehensively summarized. Although autophagy and apoptosis are significantly different in metabolic pathways and morphology, their signaling pathways are inextricably linked $(11,12)$. According to different regulation modes, their interaction can be roughly classified into three types: Cooperative, antagonistic and promotion relationships (13).

Reactive oxygen species (ROS) are produced by aerobic cells in the process of metabolism. Previous studies have demonstrated that ROS can affect a series of intracellular 
signal pathways (14). ROS regulate the balance cell death dependent on their concentration (15). Low level ROS can activate transcription factors and promote cell proliferation, differentiation and autophagy (16). However, moderate and high concentrations of ROS can induce apoptosis and autophagic cell death $(17,18)$. It has previously been demonstrated that ROS activate the mitochondrial apoptotic pathway (19). In addition, ROS have been demonstrated to activate autophagic death signaling pathway through AMP-activated protein kinase (AMPK)/mechanistic target of rapamycin (mTOR) signaling pathway (20). Previous studies have demonstrated that many anticancer drugs can stimulate the production of ROS in cancer cells, and then lead to cell apoptosis and autophagic cell death $(21,22)$.

$\alpha$-hederin, a monodesmosidic triterpenoid saponin, is a major active ingredient isolated from the leaves of ivy (Hedera helix L.) or Nigella sativa. Previous studies have demonstrated that $\alpha$-hederin has anticancer properties, which may be attributed to the inhibition of proliferation and motility $(23,24)$, induction of apoptosis $(25,26)$, membrane permeabilization (27), inhibition of epithelial to mesenchymal transition (28) and morphologic changes (27). $\alpha$-Hederin can activate the mitochondrial apoptotic pathway by increasing ROS $(24,26)$. Our previous study has reported that $\alpha$-hederin can induce apoptosis in colorectal cancer cells (29). Based on the effects of ROS on autophagy, it was suggested that $\alpha$-hederin may induce autophagy through ROS.

In the present study, to determine whether $\alpha$-hederin can induce autophagy in colorectal cancer cells, the effects of $\alpha$-hederin on colorectal cancer cells were investigated. As such, its effects on autophagy and the underlying mechanisms were explored. In addition, the interplay between the apoptosis and autophagy in colorectal cancer was also explored.

\section{Materials and methods}

Cells and reagents. HCT116 and HCT8 human colorectal cancer cells were purchased from the Type Culture Collection of the Chinese Academy of Sciences (Shanghai, China). Both cell lines were cultured in RPMI-1640 medium supplemented with $10 \%$ (v/v) fetal bovine serum (both from Gibco; Thermo Fisher Scientific, Inc., Waltham, MA, USA), $100 \mu \mathrm{g} / \mathrm{ml}$ streptomycin and $100 \mathrm{U} / \mathrm{ml}$ penicillin at $37^{\circ} \mathrm{C}$ and $5 \% \mathrm{CO}_{2}$. $\alpha$-hederin was purchased from Sigma-Aldrich; Merck KGaA (Darmstadt, Germany). ROS inhibitor N-acetyl-L-cysteine (NAC), oxidation-activated fluorescent dye DCHF-DA and Hoechst 33258 were purchased from Beyotime Institute of Biotechnology (Haimen, China). Autophagy inhibitor 3-MA was purchased from Sigma-Aldrich; Merck KGaA.

Antibodies. Anti-light chain (LC)3 (12135-1-AP), anti-caspase-9 (10380-1-AP), anti-caspase-3 (19677-1-AP), anti-P62 (18420-1-AP) and anti-Beclin 1 (11306-1-AP) antibodies were purchased from ProteinTech Group, Inc. (Chicago, IL, USA). Anti-phosphorylated (p)-mTOR (\#2971), anti-mTOR (\#2972), anti- $\beta$-actin (8456), anti-p-Unc-51 like autophagy activating kinase 1 (ULK1; \#4634), anti-ULK1 (\#4773), anti-p-P70S6K (\#9205), anti-P70S6K (\#9202), anti-poly(ADP-ribose) polymerase (PARP; \#9532), anti-p-AMPK (\#2531), anti-AMPK (\#2532), anti-B cell lymphoma (Bcl)-2 (\#2872),
anti-Bcl-2 associated $\mathrm{X}$ protein (Bax; \#2772), anti-Bcl-xl (\#2762), horseradish peroxidase (HRP)-linked anti-rabbit immunoglobulin (Ig)G (\#7074) and HRP-linked anti-mouse IgG (\#7076) were obtained from Cell Signaling Technology, Inc. (Danvers, MA, USA).

Flow cytometry assays. Flow cytometry assays were performed on a FACSCalibur system (Becton-Dickinson and Company, Franklin Lakes, NJ, USA). Apoptosis rate assay was performed using an Annexin V-fluorescein isothiocyanate (FITC)/propidium iodide (PI) apoptosis detection kit (BD Biosciences, San Jose, CA, USA). Cells were digested using trypsin, washed twice with cold PBS and then incubated with Annexin V-FITC and PI at room temperature for $30 \mathrm{~min}$. Subsequently, the apoptosis rate was determined using flow cytometry. Intracellular ROS levels were determined through flow cytometry using DCHF-DA, an oxidation-activated fluorescent dye. Cells in dishes were loaded with PBS containing $10 \mu \mathrm{M}$ DCHF-DA for $20 \mathrm{~min}$ at $37^{\circ} \mathrm{C}$. Then, cells were washed thrice with cold PBS, digested with trypsin and washed twice with cold PBS in turn. ROS assay was performed using a FACSCalibur flow cytometer (Becton-Dickinson and Company) and the data were analyzed using FlowJo software, version 7.6 (Tree Star, Inc., Ashland, OR, USA).

Hoechst 33258 staining. Cells were digested, dispersed and plated in a 96-well plate at a density of $1 \times 10^{5}$ cells/well. Cells were incubated with Hoechst $33258(0.5 \mu \mathrm{g} / \mathrm{ml}$; Beyotime Institute of Biotechnology) for $3 \mathrm{~min}$ at room temperature. Washed 3 times with PBS, cells were observed and photographed directly under a microscope.

Cell viability assay. Cells were digested, dispersed and plated in a 96-well plate at a density of $1 \times 10^{5}$ cells/well. Cell viability was analyzed using Cell Counting Kit-8 (Dojindo Molecular Technologies, Inc., Kumamoto, Japan) according to the manufacturer's protocol. Absorbances of the wells were read at $450 \mathrm{~nm}$ using a plate reader (Bio-Rad Laboratories, Inc., Hercules, CA, USA).

Colony formation assay. Single cells were seeded into a $35-\mathrm{mm}$ cell culture dish at a density of 1,000 cells/well and cultured with $\alpha$-hederin at concentrations of 0,10 and $60 \mu \mathrm{M}$ for 14 days. The medium was replaced every 2 days, a total of six times. Ultimately, cells were treated in turn with 4\% paraformaldehyde for $20 \mathrm{~min}$ and crystal for $20 \mathrm{~min}$, and were washed with PBS at least twice in room temperature. The colonies were counted, and images were captured. Colonies were determined as those able to form a colony consisting of $\geq 50$ cells.

Western blot analysis. Cells were lysed using cell lysis buffer (Beyotime Institute of Biotechnology) with Protease Inhibitor Cocktail (100X; Sangon Biotech Co., Ltd., Shanghai, China) and $1 \mathrm{mM}$ phenylmethylsulfonyl fluoride (Sigma-Aldrich; Merck KGaA). Following centrifugation at $4^{\circ} \mathrm{C}$ and $12,000 \mathrm{xg}$ for $15 \mathrm{~min}$, protein concentration in the supernatant of the lysates was determined using the Bradford Coomassie Blue G-250 method. Proteins (40 $\mu \mathrm{g}$ per lane) were separated using $10 \%$ SDS-PAGE, and transferred onto polyvinylidene 
difluoride (PVDF) membranes (EMD Millipore, Billerica, MA, USA) in sequence. Thereafter, PVDF membranes were blocked with $5 \%$ bovine serum albumin (Sigma-Aldrich; Merck KGaA) in TBS containing $0.05 \%$ Tween-20 at room temperature for $2 \mathrm{~h}$. Subsequently, PVDF membranes were incubated with primary antibodies at 1:1,000 in TBS containing $0.05 \%$ Tween-20 and 5\% bovine serum albumin overnight at $4{ }^{\circ} \mathrm{C}$ for $16 \mathrm{~h}$. Next, PVDF membranes were incubated with corresponding HRP-conjugated secondary antibodies $(1: 1,000)$ at room temperature for $2 \mathrm{~h}$. Finally, membranes were visualized using an enhanced chemiluminescence Western blot detection system (EMD Millipore). In the present study, all relative protein concentrations were normalized to that of $\beta$-actin.

Lentivirus and cell fluorescence analysis. LC3 lentivirus and mutation lentivirus were purchased from Shanghai GeneChem Co., Ltd. (Shanghai, China). The LC3 lentivirus consisted of the red fluorescent protein Stub-RFP, green fluorescent protein Sens-GFP, and autophagy marker protein LC3. HCT116 and HCT8 cells were infected with these lentiviruses to establish four cells line stably expressing LC3 (HCT116 LC3, HCT8 LC3) or LC3-mutation (HCT116 LC3-mu, HCT8 LC3-mu).

At first, cells were digested, dispersed and plated in a 24 -well plate. When cells reached $60 \%$ confluence, the medium was replaced with infection mixture. The mixture contained RPMI-1640 medium, lentiviruses (MOI=100) and polybrene (5 $\mu \mathrm{g} / \mathrm{ml}$; Shanghai GeneChem Co., Ltd.). Following incubation for $24 \mathrm{~h}$, the mixture was replaced with normal medium containing FBS. These established cell lines were used to detect the occurrence of autophagy. In the absence of autophagy, the RFP-GFP-LC3 fusion protein diffuses in the cytoplasm. When autophagy is formed, it translocates into the autophagosome membrane. The fusion protein will form bright fluorescent spots, which can be observed under fluorescence microscope. Fluorescent dot aggregation was observed via confocal laser microscopy. One spot is equivalent to an autophagosome, and the activity of autophagy can be evaluated by counting. As the control, RFP-GFP-LC3-mu fusion protein could not participate in the formation of autophagosome membrane.

RNA interference. Small interfering (si)RNA for the human AMPK gene (Gene ID: 94557300) was synthesized by Biomics Biotechnologies Co.,Ltd.(Nantong, China). The AMPK siRNA sequence was 5'-GAUAUCAGGGAACAUGAAUdTdT-3'. The control sequence was 5'-UAAGGCUAUGAAGAGAUAC-3'. Cells were transfected with the aforementioned siRNAs at a concentration of $50 \mathrm{nM}$ using Lipofectamine 3000 (Life Technologies; Thermo Fisher Scientific, Inc.) for $48 \mathrm{~h}$.

Electron microscopy. After being treated with $10 \mu \mathrm{M} \alpha$-hederin for $24 \mathrm{~h}, \mathrm{HCT} 116$ and HCT8 cells were digested with trypsin and washed twice with cold PBS. Subsequently, these cells were fixed overnight using 3\% glutaraldehyde in $0.1 \mathrm{M}$ phosphate buffer ( $\mathrm{pH} 7.2$ ) at $4^{\circ} \mathrm{C}$ and post-fixed in $1 \% \mathrm{OsO}_{4}$ buffer for $1 \mathrm{~h}$ at $4^{\circ} \mathrm{C}$. After being dehydrated in a graded series of ethanol, the cells were embedded in spur resin at $56^{\circ} \mathrm{C}$ overnight. The spur resins were cut into ultrathin sections $(60 \mathrm{~nm})$ and stained with saturated solutions of uranyl acetate and lead citrate at room temperature for $10 \mathrm{~min}$. Finally, the autophagosomes in these cells were observed using an electron microscope.

In vivo tumor xenograft model. A total of 10 male nude mice (BALB/c nu/nu; age, 5 weeks) were purchased from Shanghai SLAC Laboratory Animal Co., Ltd. (Shanghai, China). The initial body weight of all nude mice was $\sim 18 \mathrm{~g}$. Nude mice were bred in specific pathogen-free (SPF) conditions at the Laboratory Animals Breeding and Research Centre, Shanghai University of Traditional Chinese Medicine (Shanghai, China). The housing conditions for mice were as follows: Room temperature, $20-26^{\circ} \mathrm{C}$ and 12 -h light/dark cycle. The mice received $5 \mathrm{~g}$ food and $100 \mathrm{ml}$ water per $100 \mathrm{~g}$ body weight per day. Two million HCT116 cells in $0.1 \mathrm{ml}$ PBS were injected into subcutaneous tissues of each mouse. After 2 weeks, mice were weighed and randomly divided into control group and $\alpha$-hederin group ( $n=5 /$ group). $\alpha$-Hederin group mice were injected intraperitoneally with $\alpha$-hederin $(2 \mathrm{mg} / \mathrm{kg}$ body weight) and the control group were injected intraperitoneally with the same volume of PBS (control) every 3 days for 3 weeks. Finally, the tumor-bearing mice were sacrificed and the tumors were excised and weighed. The protocol was approved by the Ethics Committee of Shuguang Hospital affiliated with Shanghai University of Traditional Chinese Medicine.

Immunohistochemistry assay. All tumors from tumor xenograft model were formalin-fixed for $24 \mathrm{~h}$ at room temperature, embedded in paraffin, sectioned serially to $5-\mu \mathrm{m}$ thickness and mounted on glass slides. Subsequently, immunohistochemical staining of LC3 was carried out using a standard protocol (30). Anti-LC3 antibody (18725-1-AP; 1:50) for immunohistochemistry was purchased from ProteinTech Group, Inc. HRP-labeled goat anti-human IgG (A0201; 1:50) was purchased from Beyotime Institute of Biotechnology. Anti-LC3 antibody and HRP-labeled goat anti-human IgG were all diluted in PBS containing 5\% bovine serum albumin (Sigma-Aldrich; Merck KGaA). Meanwhile, serial sections were stained with hematoxylin and eosin (H\&E).

Statistical analysis. All data were subjected to a single-factor analysis of variance with post hoc Fisher's least significant different test, or Student's t-test using the SPSS 13.0 software package (SPSS, Inc., Chicago, IL, USA). Data are presented as the mean \pm standard deviation. $\mathrm{P}<0.05$ was considered to indicate a statistically significant difference.

\section{Results}

$\alpha$-hederin inhibits cell viability and proliferation of colorectal cancer cells. Previous studies have suggested that $\alpha$-hederin has anticancer properties against different cancers $(24,27,29,31-36)$, including colorectal cancer (29). To evaluate the effect of $\alpha$-hederin on the proliferation of colorectal cancer cells, its effect on the viability of two colorectal cancer cell lines (HCT116 and HCT8) was tested. Furthermore, colony formation assay was performed to determine cell proliferation.

In cell viability assay, HCT116 and HCT8 wells were divided into seven groups according to $\alpha$-hederin 

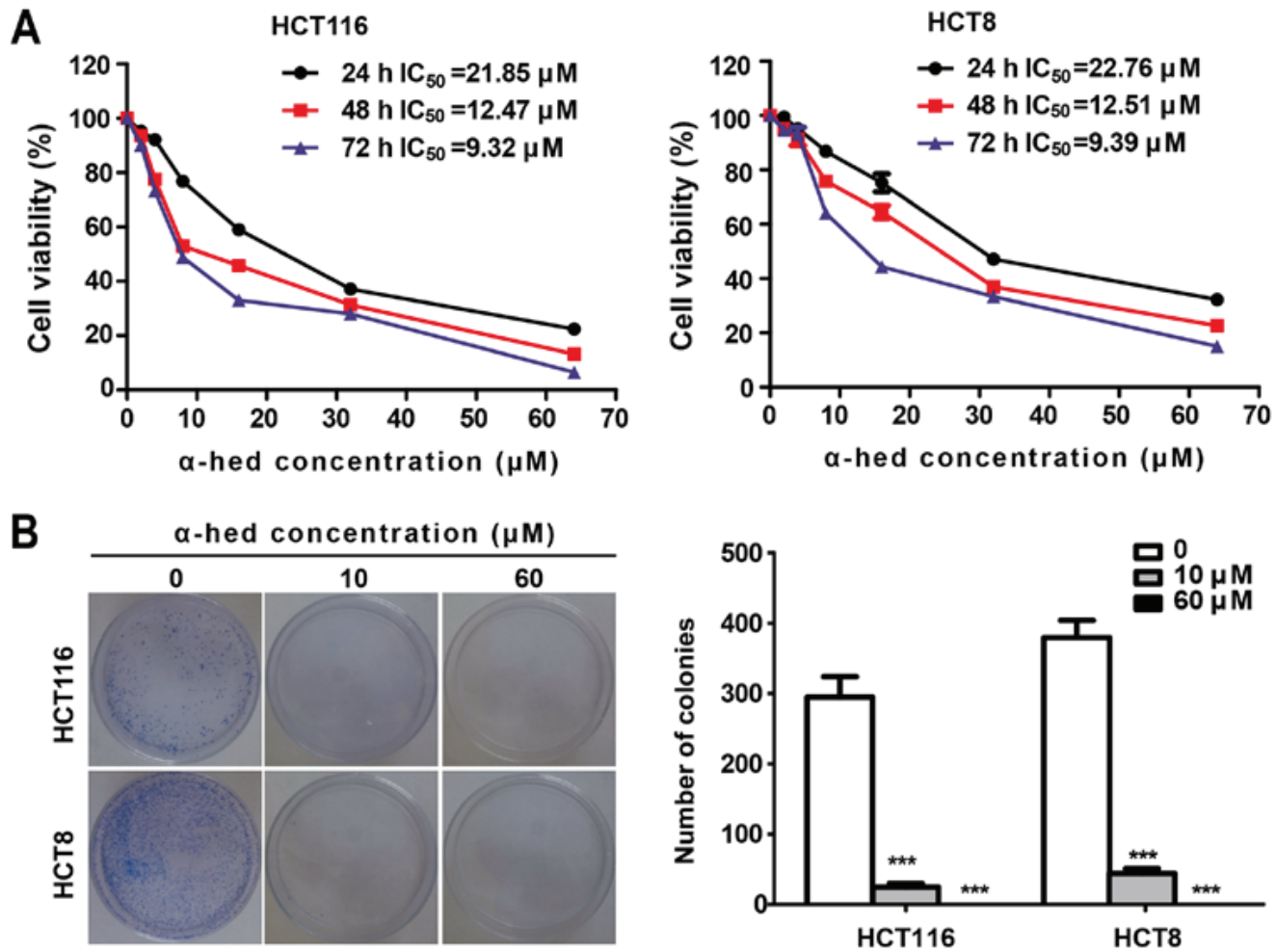

Figure 1. $\alpha$-hederin inhibits colorectal cancer cell proliferation. (A) $\alpha$-hederin inhibits cell viability of colorectal cancer cells. Colorectal cancer cell lines HCT8 and HCT116 were incubated with increasing doses of $\alpha$-hederin $(0-64 \mu \mathrm{M})$ for 24,48 and $72 \mathrm{~h}$ to analyze cell proliferation using cell counting kit-8 assay. (B) $\alpha$-hederin inhibits colony formation of colorectal cancer cells. HCT8 and HCT116 were incubated with $\alpha$-hederin at 0,10 and $60 \mu \mathrm{M}$ for 10 days. Representative colony images are presented. ${ }^{* * *} \mathrm{P}<0.001$ vs. $0 \mu \mathrm{M}$. $\alpha$-hed, $\alpha$-hederin; $\mathrm{IC}_{50}$, half maximal inhibitory concentration.

concentration $(0,2,4,8,16,32$ and $64 \mu \mathrm{M})$. Each group contained six wells. As presented in Fig. 1A, the cell viability of the two cell lines decreased significantly with the increase of $\alpha$-hederin concentration. The half maximal inhibitory concentration $\left(\mathrm{IC}_{50}\right)$ of $\alpha$-hederin in HCT116 was $21.85,12.47$ and $9.32 \mu \mathrm{M}$ for 24,48 and $72 \mathrm{~h}$, respectively. Similarly, $\mathrm{IC}_{50}$ values of $\alpha$-hederin in HCT8 cells treated for 24,48 and $72 \mathrm{~h}$ were $22.76,12.51$ and $9.39 \mu \mathrm{M}$, respectively. Therefore, $\alpha$-hederin decreased the viability of both colorectal cancer cell lines in a dose- and time-dependent manner. Colony formation assay using the adhesive culture system was used to analyze the antiproliferation effects of $\alpha$-hederin. It was demonstrated that $\alpha$-hederin treatment resulted in a dose-dependent decrease in the efficiency of colony formation (Fig. 1B). $\alpha$-Hederin concentrations at $10 \mu \mathrm{M}$ caused a significant decreased in the number of colonies in both colorectal cancer cell lines $(\mathrm{P}<0.001)$. Furthermore, after increasing $\alpha$-hederin concentrations to $60 \mu \mathrm{M}$, no colonies were observed.

$\alpha$-hederin induces apoptosis in colorectal cancer cells. Previous studies have demonstrated that $\alpha$-hederin may induce cell apoptosis $(27,37)$. In the present study, $\alpha$-hederin-induced apoptosis rates of colorectal cancer cells were determined using flow cytometry with Annexin V/PI (Fig. 2A) and microscopy using Hoechst 33258 staining (Fig. 2B). Flow cytometry results indicated that the $\alpha$-hederin-induced $(0,10$ and $60 \mu \mathrm{M})$ apoptosis rates were $5.51 \pm 1.18,8.97 \pm 1.69$ and $21.75 \pm 2.85 \%$ in HCT116 cells. Apoptosis rates in HCT8 cells were $3.54 \pm 1.3$, $7.66 \pm 1.89$ and $15.66 \pm 2.36 \%$ (Fig. 2A). Compared with control, $10 \mu \mathrm{M} \alpha$-hederin induced higher levels of apoptosis in HCT116 and HCT8 cells ( $\mathrm{P}<0.01)$, with $60 \mu \mathrm{M} \alpha$-hederin inducing even greater levels of apoptosis $(\mathrm{P}<0.001)$. In addition, Hoechst 33258 staining exhibited results similar to those for flow cytometry (Fig. 2B).

The mitochondrial signaling pathway is one of the major pathways involved in apoptosis (38). To observe the effect of $\alpha$-hederin on the mitochondrial signal pathway, the expression of mitochondrial apoptosis-related proteins was measured in HCT116 cells. As presented in Fig. 2C, compared with the control, the expression of activated caspase-9 (cleaved caspase-9), activated caspase-3 (cleaved caspase-3), PARP degradation (cleaved PARP), and Bax were all increased in HCT116 cells treated with $\alpha$-hederin. Furthermore, $\alpha$-hederin increased these proteins expression of HCT116 cells in a time-dependent manner. Conversely, $\alpha$-hederin decreased the expression of Bcl-2 and Bcl-xl in a time-dependent manner.

$\alpha$-hederin induces autophagy in colorectal cancer cells. Analysis of Figs. 1A and 2A indicated that the apoptosis rate did not match the inhibition rate of $\alpha$-hederin on colorectal cancer cell viability. This suggested that $\alpha$-hederin-induced cell death may have involved other mechanisms. Autophagy rates in HCT116 and HCT8 cells were determined using LC3 lentivirus (39). As a negative control, mutant LC3 (LC3-mu) was used as it could not bind to autophagosomes and form bright fluorescent spots. As presented in Fig. 3A, $\alpha$-hederin induced LC3 but not LC3-mu aggregation in HCT116 and HCT8 cells. Compared with controls, $10 \mu \mathrm{M} \alpha$-hederin exhibited significantly higher autophagic rate in HCT116 and HCT8 cells $(\mathrm{P}<0.001)$. The presence of autophagosomes in 


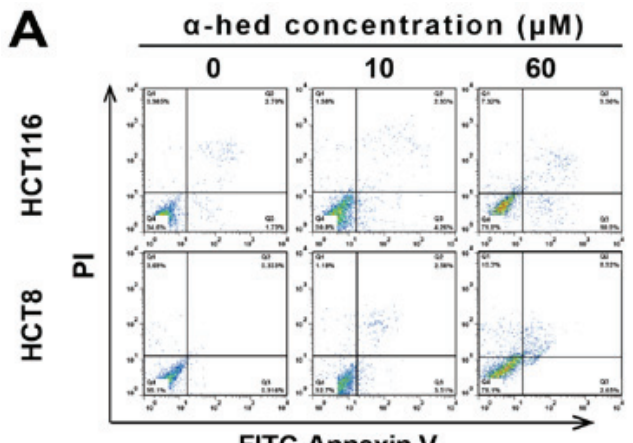

FITC-Annexin V

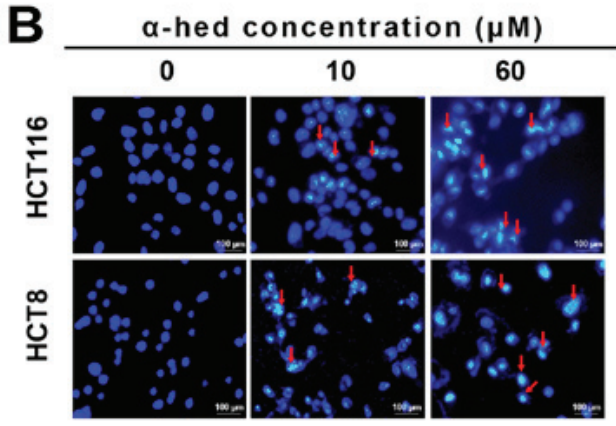

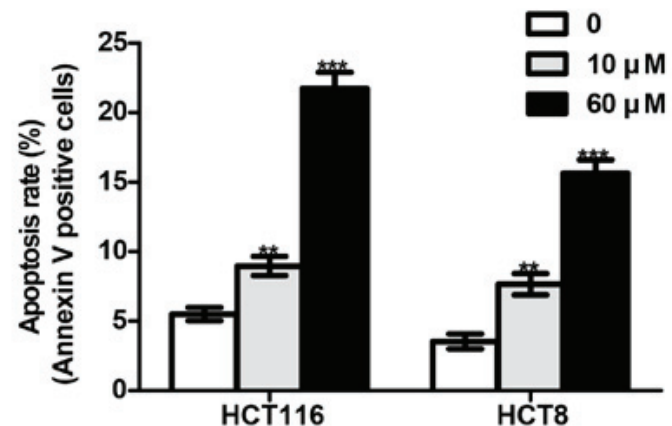

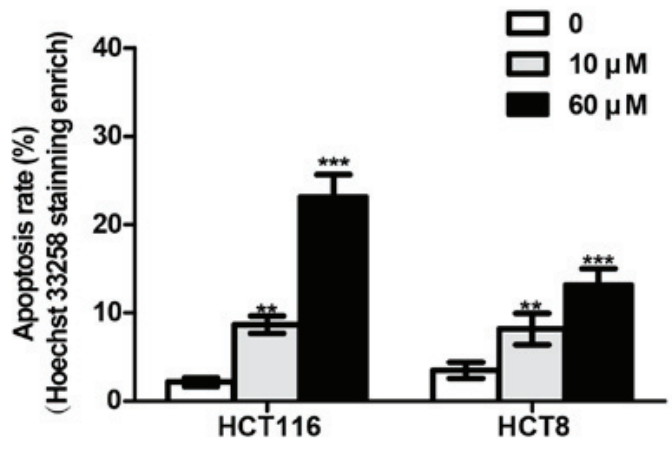

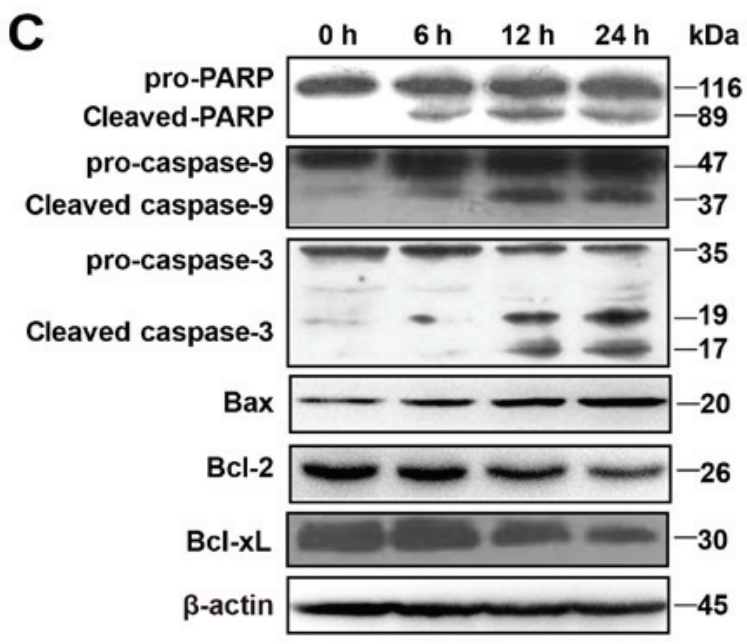

Figure 2. $\alpha$-hederin induces colorectal cancer cell apoptosis. (A) Apoptosis analysis of $\alpha$-hederin-treated cells through flow cytometry using Annexin V/PI HCT8 and HCT116 cells were treated with 0,10 and $60 \mu \mathrm{M} \alpha$-hederin for $24 \mathrm{~h}$. (B) Apoptosis analysis of $\alpha$-hederin-treated cells through microscopy using Hoechst 33258 staining (magnification, x200). Following treatment with $\alpha$-hederin for 24 h, Hoechst 33258 staining was used to identify apoptotic cells (red arrows). Histograms on the right represent apoptosis rates following Hoechst 33258 staining enrichment. (C) HCT116 cells were treated with $10 \mu \mathrm{M} \alpha$-hederin for 6,12 and $24 \mathrm{~h}$, after which their lysates were analyzed by western blotting for mitochondrial apoptosis pathway protein levels using anti-PARP, anti-caspase-9, anti-caspase-3, anti-Bax, anti-Bcl-2, and anti-Bcl-xL antibody. ${ }^{* *} \mathrm{P}<0.01,{ }^{* * *} \mathrm{P}<0.001$ vs. $0 \mu \mathrm{M}$. PI, propidium iodide; $\alpha$-hed, $\alpha$-hederin; FITC, fluorescein isothiocyanate; PARP, poly (ADP-ribose) polymerase; Bcl, B cell lymphoma; Bax, Bcl associated X protein.

HCT116 cells was also evaluated using an electron microscope. As presented in Fig. 3B, autophagosomes were present in $\alpha$-hederin-treated HCT116 and HCT8 cells. This result further supported that $\alpha$-hederin induced autophagy in colorectal cancer cells.

Effect of $\alpha$-hederin on LC3 expression in vivo. In vitro results had demonstrated that $\alpha$-hederin could induce autophagy in colorectal cancer cells. To investigate the inducing autophagy effect of $\alpha$-hederin in vivo, a subcutaneous xenograft model of HCT116 cells in nude mice was used. As presented in Fig. 4A, $\alpha$-hederin significantly inhibited tumor growth compared with the control. According to the results of H\&E staining (Fig. 4B), tumors treated with $\alpha$-hederin exhibited marked necrosis. LC3 puncta was assessed using immunohistochemistry to evaluate the effect of $\alpha$-hederin on autophagy in vivo. As presented in Fig. 4B, the presence of $\mathrm{LC} 3$ puncta was observed in samples treated with $\alpha$-hederin. In addition, the necrotic area also exhibited highly aggregated LC3 puncta. While, the control exhibited significant diffuse cytoplasmic staining without puncta. These results suggested that $\alpha$-hederin could inhibit tumorigenicity through promoting autophagy of colorectal cancer cells in vivo.

$\alpha$-hederininduces autophagy of colorectal cancer cells through the AMPK/mTOR pathway. Given that dephosphorylation of 

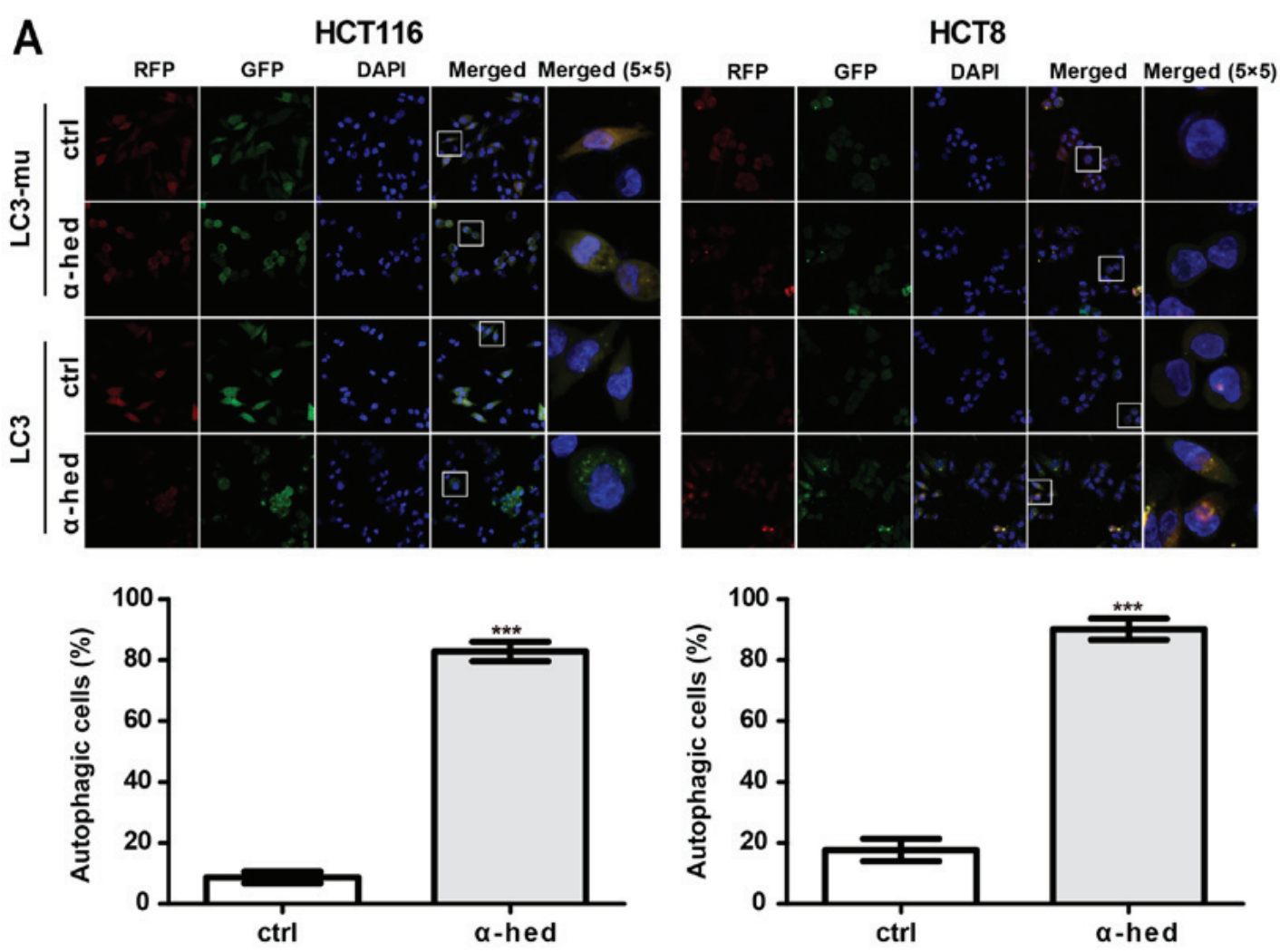

B

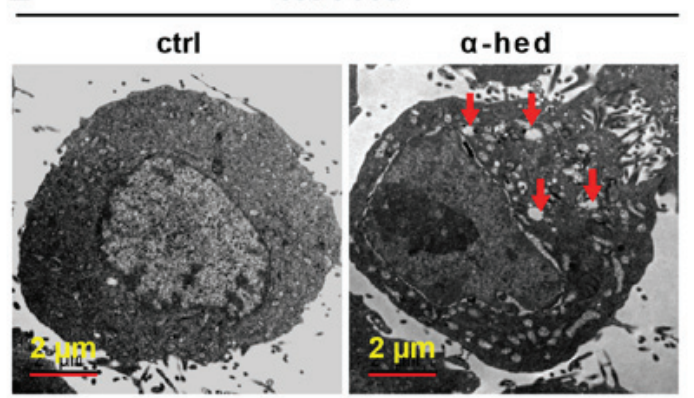

\section{HCT116}

НСТ8

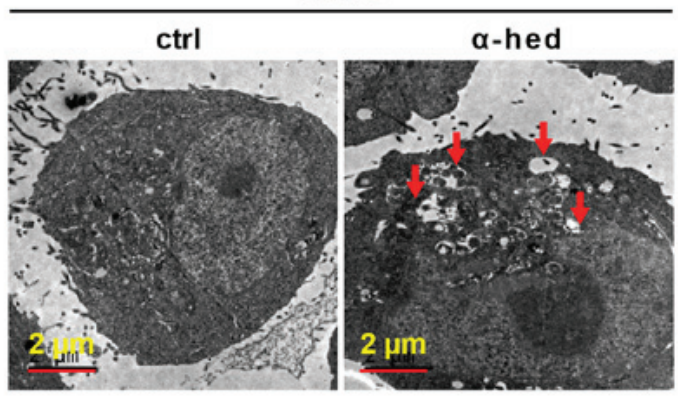

Figure 3. $\alpha$-hederin induces autophagy in colorectal cancer cells. (A) HCT116 and HCT8 cells were infected with LC3 and LC3-mu. After these cells were treated with $10 \mu \mathrm{M} \alpha$-hederin for $24 \mathrm{~h}$, autophagy rate assay was then performed. Images were captured using laser confocal microscopy. Magnification of (RFP, GFP, DAPI and Merge magnification, x400; Merge 5x5 magnification, x10,000. Histograms present autophagy rates according to the proportion of highlighted cells. (B) Normal and autophagic HCT116 and HCT8 cells were photographed using an electron microscope. Red arrows in the graphs represent autophagosomes. ${ }^{* * *} \mathrm{P}<0.001$ vs. ctrl. LC3, light chain 3 lentivirus; LC3-mu, mutation light chain 3 lentivirus; $\alpha$-hed, $\alpha$-hederin; ctrl, control.

p-mTOR and degradation of LC3 I to LC3 II are the major mechanisms involved in autophagy (40), LC3 II protein levels were used to determine the extent of cell autophagy (41). After treating HCT116 cells with $\alpha$-hederin for $24 \mathrm{~h}$, cell lysates were used to detect p-mTOR and LC3 II protein levels. As presented in Fig. 5A, an increase in $\alpha$-hederin concentration resulted in a gradual increase in LC3 II levels but a gradual decrease in p-mTOR protein levels. HCT116 cells were also treated with $10 \mu \mathrm{M} \alpha$-hederin for 6,12 and $24 \mathrm{~h}$. The results demonstrated that, over time, $\alpha$-hederin caused a gradual decrease in p-mTOR, p-ULK1, p-P70S6K and P62 protein levels but a gradual increase in $\mathrm{p}-\mathrm{AMPK}$ and beclin-1 protein levels (Fig. 5B).

AMPK/mTOR is a major signaling pathway involved in autophagy (42). In this signaling pathway, AMPK serves as the activator of autophagy. AMPK activation induces dephosphorylation of mTOR, which separates it from the ULK1 complex. The subsequent dephosphorylation of ULK1 then initiates autophagy (43). To verify the role of the AMPK/mTOR pathway in $\alpha$-hederin-induced autophagy, the expression of autophagy-related signals was detected in HCT116 cells treated with AMPK siRNA. It was demonstrated that AMPK siRNA restored the expression of p-mTOR, p-P70S6K and p-ULK1, which had been decreased by $\alpha$-hederin (Fig. 5C). Results for p-AMPK indicated that although $\alpha$-hederin increased LC3 II, AMPK knockdown did not restore LC3 II.

ROS-dependent AMPK activation by $\alpha$-hederin. Previous studies have demonstrated that ROS is a major factor in 
A
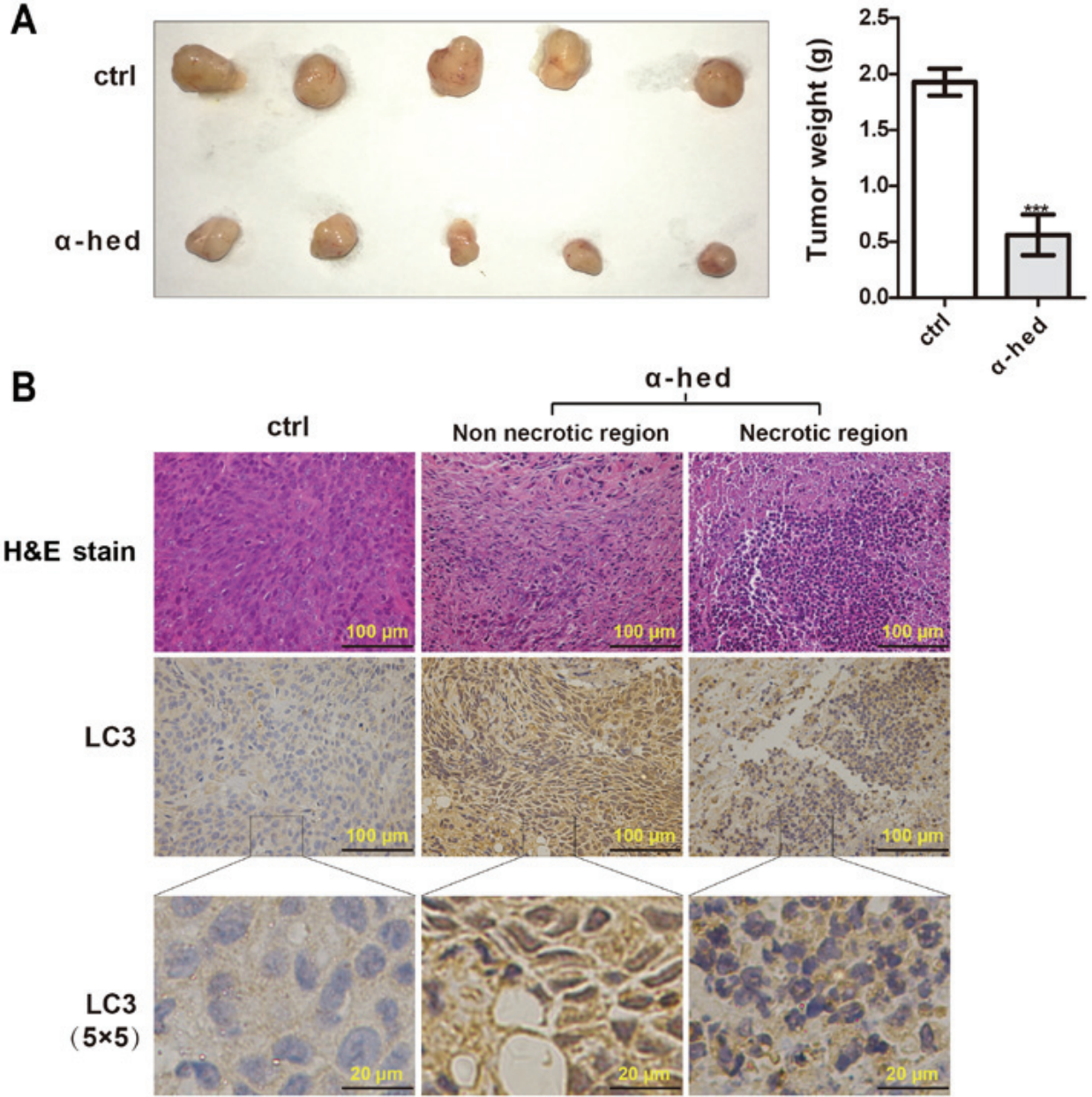

Figure 4. $\alpha$-hederin inhibits the proliferation and promotes the production of LC3 II in colorectal cancer cells in vivo. A subcutaneous xenograft model of HCT116 cells was treated with $\alpha$-hederin for 3 weeks. (A) Tumors were photographed and weighed. (B) H\&E staining was used to evaluate the differences of tissue morphology. Immunohistochemistry was performed to evaluate the expression of autophagic marker LC3. ${ }^{* * *} \mathrm{P}<0.001$ vs. ctrl. LC3, light chain 3 ; H\&E, hematoxylin and eosin; $\alpha$-hed, $\alpha$-hederin; ctrl, control

$\alpha$-hederin-induced apoptosis $(37,44)$. ROS production is also important for AMPK/mTOR pathway activation. To verify the role of ROS in $\alpha$-hederin-induced AMPK/mTOR pathway activation, oxidation-activated fluorescent dye DCHF-DA was used to detect intracellular ROS using flow cytometry. HCT116 cells were treated with $10 \mu \mathrm{M}$ each of $\alpha$-hederin and ROS inhibitor NAC for $24 \mathrm{~h}$ at $37^{\circ} \mathrm{C}$ then incubated in RPMI-1640 medium supplemented with $5 \mu \mathrm{mol} / \mathrm{ml}$ DCHF-DA for $30 \mathrm{~min}$ at room temperature. Fig. 6A demonstrated that although $\alpha$-hederin increased ROS levels, ROS inhibitor NAC reversed this effect. Furthermore, NAC inhibited $\alpha$-hederin-induced AMPK/mTOR pathway activation (Fig. 6B). Subsequently, the effects of NAC and $\alpha$-hederin on apoptosis were detected by flow cytometry. As presented in Fig. 6C, NAC alone did not affect the apoptosis rate but NAC reduced the apoptosis rate treated by $\alpha$-hederin in HCT116 cells $(\mathrm{P}<0.001)$. Additional, results from confocal microscopy demonstrated that NAC could inhibit $\alpha$-hederin-induced autophagy (Fig. 6D).

Autophagy and apoptosis comprise the major mechanisms by which $\alpha$-hederin induces colorectal cancer cell death. To clarify the interplay between apoptosis and autophagy induced by $\alpha$-hederin in colorectal cancer, the effects of autophagy inhibitor 3-MA on apoptosis and autophagy were investigated. HCT116 cells were treated with $2 \mathrm{mM} 3-\mathrm{MA}$ for $48 \mathrm{~h}$ to evaluate the effect of 3-MA alone on cell viability. The results indicated that $2 \mathrm{mM} 3$-MA alone had no significant effect on cell viability of HCT116 cells (Fig. 7A). Then, HCT116 cells were treated with $\alpha$-hederin $(2,4,8,16,32$ and $64 \mu \mathrm{M})$ or $\alpha$-hederin plus $2 \mathrm{mM} 3$-MA for $48 \mathrm{~h}$, after which cell viability was tested. As presented in Fig. 7B, 2 mM 3-MA significantly reduced the effect of $\alpha$-hederin on cell viability $(\mathrm{P}<0.05)$. Furthermore, HCT116 cells were treated with 2 mM 3-MA, $10 \mathrm{mM} \alpha$-hederin and $2 \mathrm{mM} 3$-MA with $10 \mathrm{mM} \alpha$-hederin for 48 h. As presented in Fig. 7C, 3-MA had no significant effect on $\alpha$-hederin-induced apoptosis. Finally, apoptosis rate was detected by flow cytometry. It was also demonstrated that 3-MA blocked the $\alpha$-hederin-induced autophagosome formation (Fig. 7D).

\section{Discussion}

$\alpha$-Hederin, a novel type of drug derived from the leaves of ivy or Nigella sativa, had exhibited strong anticancer activities in recent studies. Previous studies had demonstrated that $\alpha$-hederin could induce cell apoptosis $(23,26,27,37)$. In the present study, it was demonstrated that $\alpha$-hederin activated the 
A

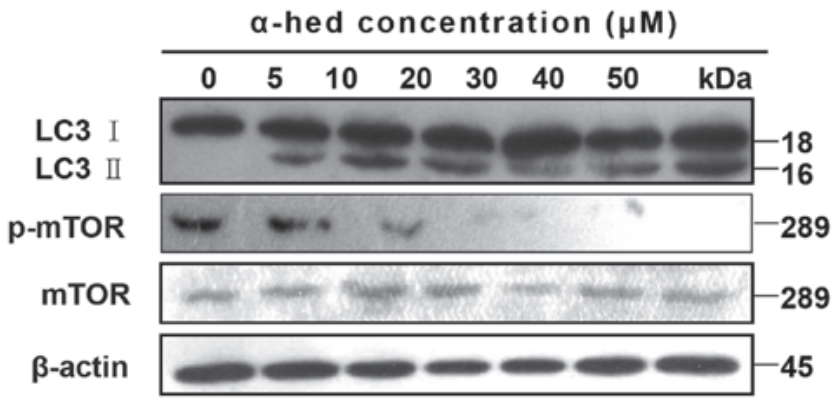

B

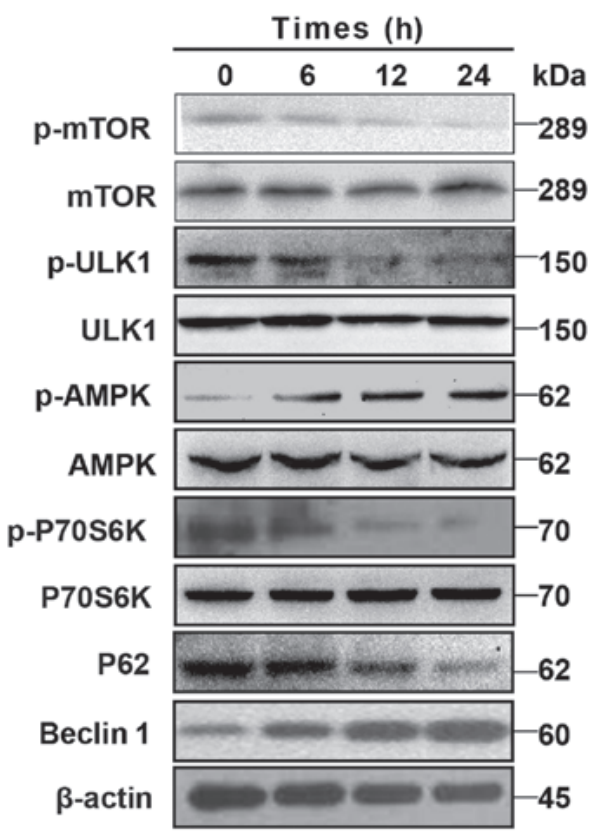

C

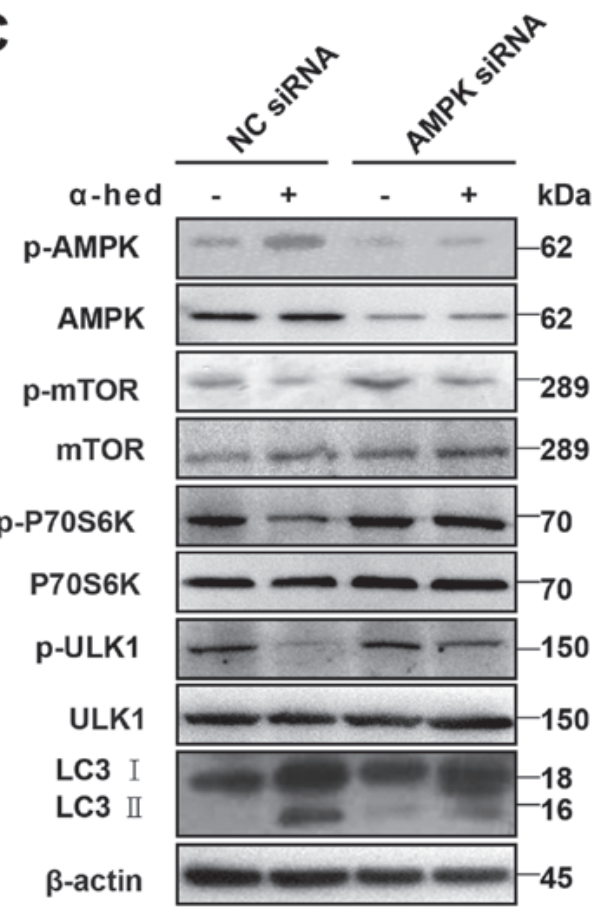

Figure 5. AMPK/mTOR pathway participated in $\alpha$-hederin-induced autophagy. (A) $\alpha$-hederin upregulated LC3 II levels and inhibited p-mTOR in a dose-dependent manner. (B) After HCT116 cells were treated with $10 \mu \mathrm{M} \alpha$-hederin for 6, 12 and $24 \mathrm{~h}$, expression levels of p-mTOR, mTOR, p-ULK1, ULK1, p-AMPK, AMPK, p-P70S6K, P70S6K, P62 and beclin1 were determined using specific antibodies. (C) HCT116 cells were treated with AMPK siRNA and NC siRNA for 3 days, with $\alpha$-hederin being added during the last 2 days. The expression levels of p-AMPK, AMPK, p-mTOR, mTOR, p-ULK1, ULK1, p-P70S6K, P70S6K and LC3 were then evaluated using western blotting. AMPK, AMP-activated protein kinase; mTOR, mechanistic target of rapamycin; LC3, light chain 3; p, phosphorylated; ULK1, Unc-51 like autophagy activating kinase 1; siRNA, small interfering RNA; NC, normal control; $\alpha$-hed, $\alpha$-hederin.

mitochondrial apoptosis signal pathway in colorectal cancer cells. However, the results also demonstrated that the rate of apoptosis induced by $\alpha$-hederin was not consistent with its inhibitory effects on colorectal cancer cells, suggesting that other mechanisms may be involved in the anticancer activity of $\alpha$-hederin.

Previous studies had demonstrated that autophagy regulated by $\alpha$-hederin was differently in different cells: $\alpha$-hederin induced autophagy in neuronal PC12 cell (45) but inhibited autophagy in non-small cell lung cancer cells (44). In the present study, autophagosomes were observed in two colorectal cancer cell lines (HCT116 and HCT8) treated with $\alpha$-hederin by fluorescence microscopy using LC3 lentivirus and electron microscopy. In view of the high toxicity of $\alpha$-hederin, low-dose ( $2 \mathrm{mg} / \mathrm{kg}$ body weight) $\alpha$-hederin was used for intraperitoneal injection. The results also demonstrated that $\alpha$-hederin could induce autophagy in colorectal cancer cells in vivo.

The mTOR pathway is a typical signaling pathway that regulates cell autophagy (40). LC3, a subunit of the microtubule-associated proteins involved in the formation of autophagic vacuoles, is regarded as an autophagy marker (41). It was demonstrated that $\alpha$-hederin was able to decrease the expression of p-mTOR and increase the ratio of LC3II/I in a concentration-dependent manner. Which suggested that $\alpha$-hederin could activate autophagy mediated by the mTOR signaling pathway.

AMPK signaling is one major regulatory signal of mTOR signaling pathway and autophagy (46). In addition, $\alpha$-hederin is able to induce AMPK/mTOR dependent autophagy and promote the degradation of neurodegenerative mutant disease protein (45). The expression of AMPK/mTOR signaling pathway related proteins and autophagy-related proteins were also detected. The results demonstrated that $\alpha$-hederin could induce AMPK-mTOR dependent autophagy in HCT116 cells. In addition, this autophagy could be blocked by the AMPK siRNA. It suggested that the AMPK/mTOR signaling pathway served a major role in $\alpha$-hederin-induced autophagy. 
A
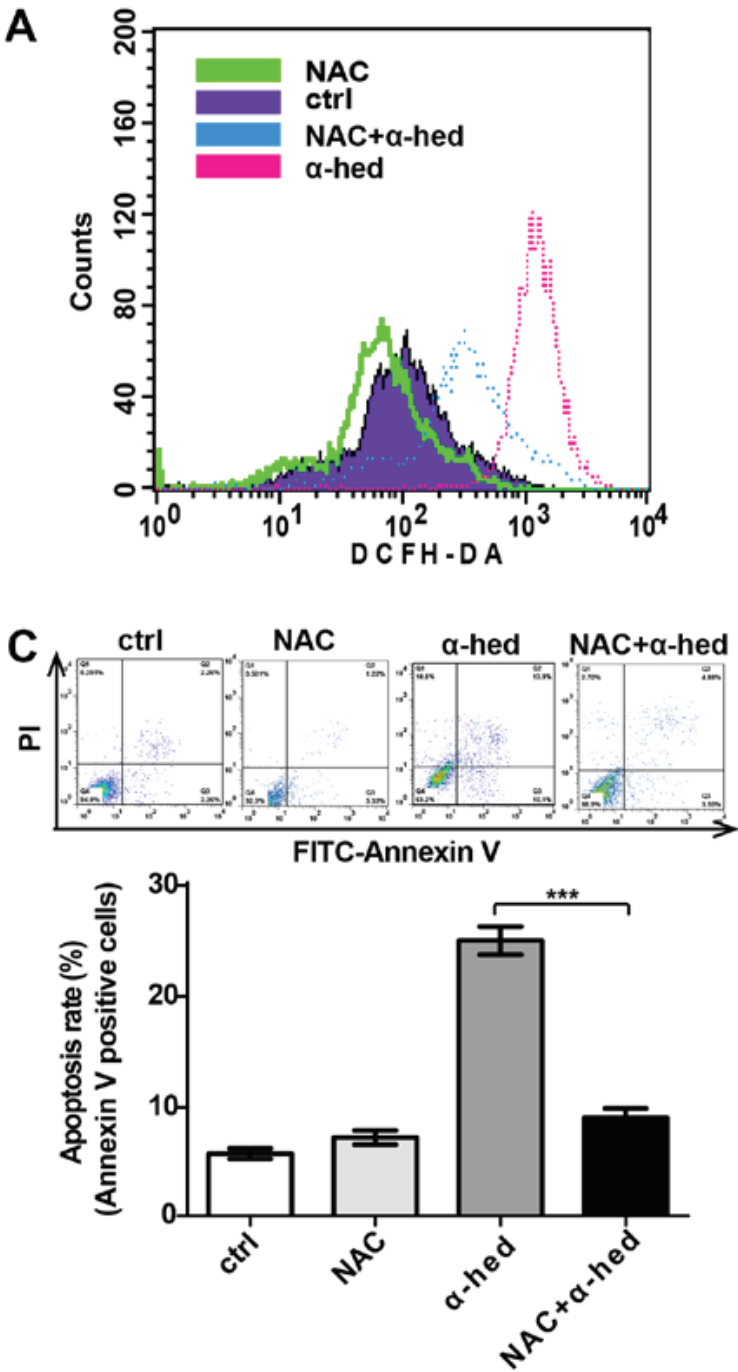

B
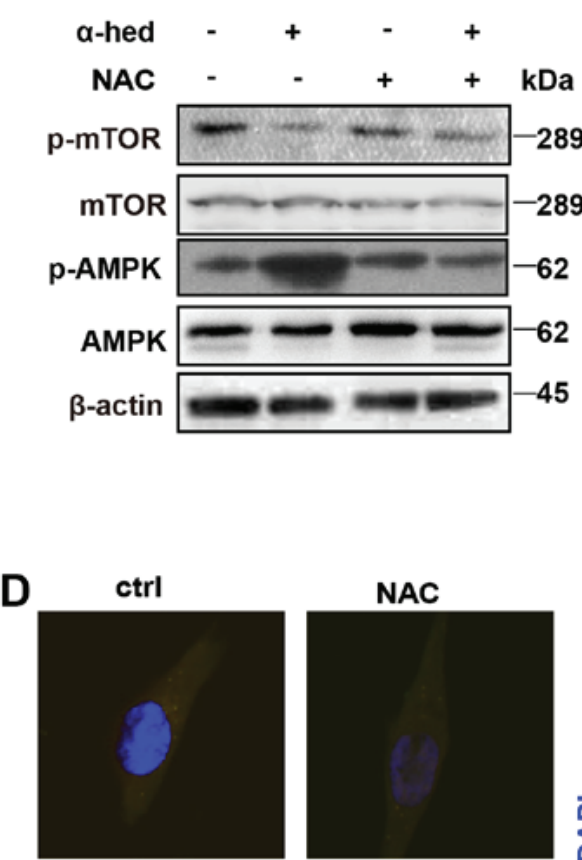

a-hed

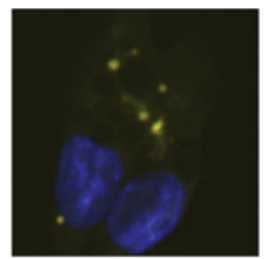

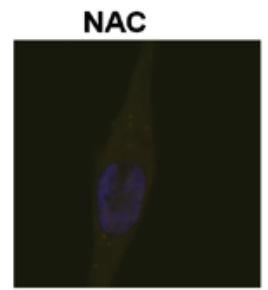

NAC+a-hed

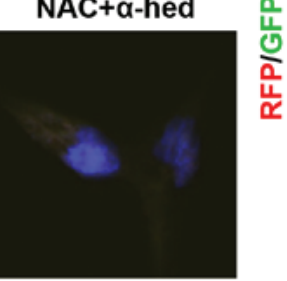

Figure 6. $\alpha$-hederin-induced AMPK pathway activation depended on ROS. (A) After being treated with $10 \mu \mathrm{M} \alpha$-hederin or ROS inhibitor NAC (10 $\mu$ M) for $24 \mathrm{~h}, \mathrm{HCT} 116$ cells were dyed with oxidation-activated fluorescent dye DCHF-DA and analyzed using flow cytometry to detect intracellular ROS. (B) After being treated with $10 \mu \mathrm{M} \alpha$-hederin or ROS inhibitor NAC (10 $\mu \mathrm{M})$ for $24 \mathrm{~h}$, western blotting was used to test HCT116 cell lysates for p-mTOR and p-AMPK expression levels. Following treatment with $\alpha$-hederin, NAC and NAC plus $\alpha$-hederin for 24 h, (C) The apoptosis rate of HCT116 cells was tested by flow cytometry. (D) Light chain 3 fluorescence of HCT116 cells was photographed via confocal microscopy (magnification, x400). *** P<0.001. AMPK, AMP-activated protein kinase; ROS, reactive oxygen species; mTOR, mechanistic target of rapamycin; p, phosphorylated; $\alpha$-hed, $\alpha$-hederin; ctrl, control; PI, propidium iodide; FITC, fluorescein isothiocyanate.

ROS production has been regarded as the ideal anticancer mechanism for many drugs $(37,47)$ given that it activates both apoptosis and autophagy to kill cancer cells (48). In the present study, ROS levels of HCT116 cells treated with $\alpha$-hederin were determined using DCHF-DA. The results demonstrated that although $\alpha$-hederin increased ROS levels, NAC reversed this effect. The results of western blotting demonstrated that NAC blocked the $\alpha$-hederin-induced activation of the AMPK/mTOR signaling pathway. This suggested that the $\alpha$-hederin-induced AMPK/mTOR signaling pathway activation depended on ROS production. In addition, NAC could reverse the apoptosis and autophagy induced by $\alpha$-hederin. These results suggested that increasing ROS may serve a key role for the anticancer effects of $\alpha$-hederin.

Autophagy is one of the major mechanisms involved in cancer cell apoptosis and drug resistance during the treatment of various cancers (49). This is primarily because drugs stimulate the cell's protective autophagy and inhibit cell apoptosis (50).
However, a number of studies have demonstrated that certain drugs cause not only excessive autophagy in specific tumor cells, but also autophagic cell death $(51,52)$, making autophagy their main anticancer mechanism. Therefore, considering that different drugs act on different cells, their autophagic and apoptotic outcomes may be different. This may have been caused by differing activation of the signaling pathway (53). In the present study, it was demonstrated that autophagy inhibitor 3-MA significantly reduced the anticancer effects of $\alpha$-hederin. Furthermore, 3-MA had no significant effects on $\alpha$-hederin-induced apoptosis in HCT116 cells. These results suggest that autophagy and apoptosis are equally important mechanisms through which $\alpha$-hederin exerts its anticancer effects.

In conclusion, the present findings suggest that $\alpha$-hederin may stimulate ROS production in colorectal cancer cells and activate both autophagy and apoptosis, both of which increase the anticancer effects of $\alpha$-hederin. Autophagy is 
A

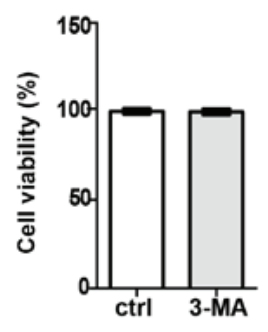

B

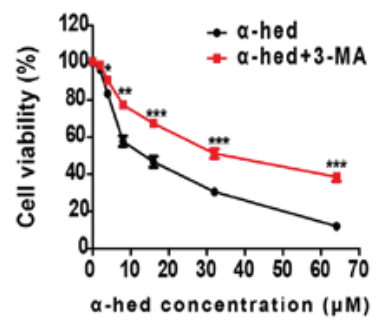

C
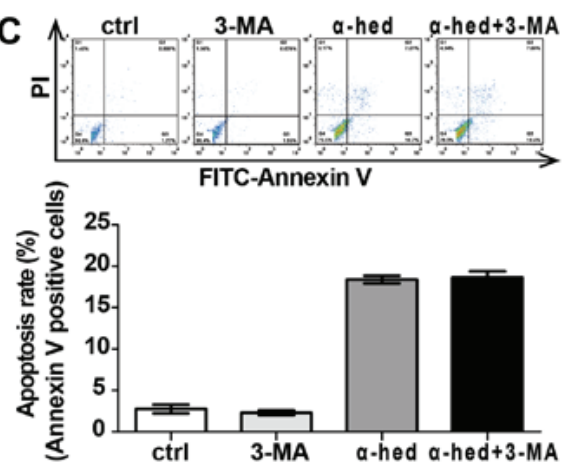

D

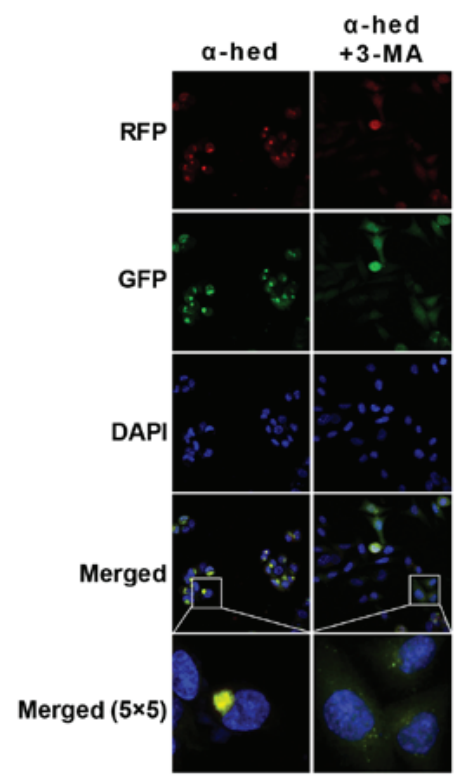

E

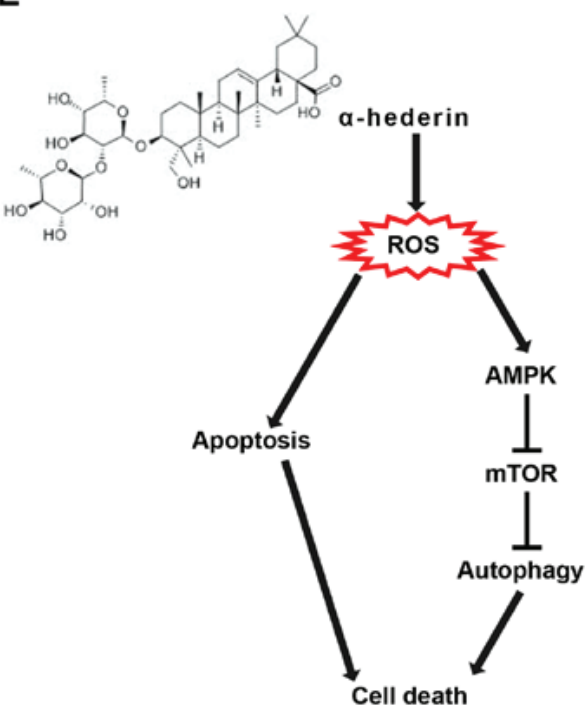

Figure 7. Cell death induced by $\alpha$-hederin depended on apoptosis and autophagy. (A) HCT116 was treated with 2 mM 3 -MA for 24 h. CCK8 was used to evaluate the effects of $2 \mathrm{mM} 3$-MA alone on the cell viability. (B) HCT116 was incubated with $10 \mu \mathrm{M} \alpha$-hederin or $10 \mu \mathrm{M} \alpha$-hederin plus $2 \mathrm{mM} 3$-MA for $24 \mathrm{~h}$. Thereafter, CCK8 assay was used to detect cell viability. (C) HCT116 was incubated with $10 \mu \mathrm{M} \alpha$-hederin, 2 mM 3 -MA or $10 \mu \mathrm{M} \alpha$-hederin plus 2 mM 3 -MA for $24 \mathrm{~h}$. Apoptosis assay by flow cytometry was used to determine the effect of 3-MA on $\alpha$-hederin induced apoptosis. (D) Light chain 3 lentivirus-infected HCT116 cells were treated with $10 \mu \mathrm{M} \alpha$-hederin or $10 \mu \mathrm{M} \alpha$-hederin plus $2 \mathrm{mM} 3$-MA for $24 \mathrm{~h}$. Autophagosomes were then photographed using laser confocal microscopy (RFP, GFP, DAPI and Merge magnification, x400; Merge 5x5 magnification, x10,000). (E) Model of the mechanism for $\alpha$-hederin induced colorectal cancer cell death. ${ }^{*} \mathrm{P}<0.05,{ }^{* *} \mathrm{P}<0.01,{ }^{* * *} \mathrm{P}<0.001$ vs. $\alpha$-hed. CCK8, cell counting kit 8; ctrl, control; $\alpha$-hed, $\alpha$-hederin; PI, propidium iodide; FITC, fluorescein isothiocyanate; ROS, reactive oxygen species.

produced by the ROS-activated AMPK/mTOR signaling pathway (Fig. 7E). With its strong anticancer effect and multiple anticancer mechanisms, $\alpha$-hederin may potentially become a more reliable anticancer drug. However, due to its strong toxicity (54-57), protein absorption (58) and hemolytic effect (59), further molecular modifications and nanotarget drug carriers should be applied during the anticancer study of $\alpha$-hederin.

\section{Acknowledgements}

Not applicable.

\section{Funding}

The present study was supported by the International Cooperation Key Project of the National Natural Science Foundation of China (grant no. 81520108031), the National Natural Science Foundation of China (grant no. 81473478), Shanghai Academic Research Leader (grant no. 16XD1403600), Shanghai Rising-Star Program (grant no. 16QA1403700), Municipal Human Resources Development Program for Outstanding Leaders in Medical Disciplines in Shanghai (grant no. 2017BR031) and Shanghai University of Traditional Chinese Medicine (grant no. 18LK042).

\section{Availability of data and materials}

All data generated or analyzed during this study are included in this published article or are available from the corresponding author on reasonable request.

\section{Authors' contributions}

JS, YF, YW, QJ, GC, LS, YW, YH, JZ and QL performed the experiments and data analysis, and wrote the manuscript. JS made substantial contributions to the design of the present study and acquired experimental materials. JZ and QL served a key role in guiding the subject, providing funding and writing the manuscript. All authors read and approved the final manuscript. 


\section{Ethics approval and consent to participate}

The animal protocol was approved by the Ethics Committee of Shuguang Hospital affiliated with Shanghai University of Traditional Chinese Medicine.

\section{Patient consent for publication}

Not applicable.

\section{Competing interests}

The authors declare that they have no competing interests.

\section{References}

1. Jemal A, Bray F, Center MM, Ferlay J, Ward E and Forman D: Global cancer statistics. CA Cancer J Clin 61: 69-90, 2011.

2. Center MM, Jemal A, Smith RA and Ward E: Worldwide variations in colorectal cancer. CA Cancer J Clin 59: 366-378, 2009.

3. Siegel R, Desantis C and Jemal A: Colorectal cancer statistics, 2014. CA Cancer J Clin 64: 104-117, 2014.

4. Koehler BC, Jäger D and Schulze-Bergkamen H: Targeting cell death signaling in colorectal cancer: Current strategies and future perspectives. World J Gastroenterol 20: 1923-1934, 2014.

5. Green DR and Llambi F: Cell death signaling. Cold Spring Harb Perspect Biol 7: a006080, 2015.

6. Kroemer G, Galluzzi L, Vandenabeele P, Abrams J, Alnemri ES, Baehrecke EH, Blagosklonny MV, El-Deiry WS, Golstein P, Green DR, et al; Nomenclature Committee on Cell Death 2009: Classification of cell death: Recommendations of the Nomenclature Committee on Cell Death 2009. Cell Death Differ 16: 3-11, 2009.

7. Shintani T and Klionsky DJ: Autophagy in health and disease: A double-edged sword. Science 306: 990-995, 2004.

8. $\mathrm{Ng} \mathrm{G}$ and Huang J: The significance of autophagy in cancer. Mol Carcinog 43: 183-187, 2005.

9. Codogno P and Meijer AJ: Autophagy and signaling: Their role in cell survival and cell death. Cell Death Differ 12 (Suppl 2): $1509-1518,2005$

10. Su M, Mei Y and Sinha S: Role of the crosstalk between autophagy and apoptosis in cancer. J Oncol 2013: 102735, 2013.

11. Ouyang L, Shi Z, Zhao S, Wang FT, Zhou TT, Liu B and Bao JK: Programmed cell death pathways in cancer: A review of apoptosis, autophagy and programmed necrosis. Cell Prolif 45 : 487-498, 2012

12. Ou L, Lin S, Song B, Liu J, Lai R and Shao L: The mechanisms of graphene-based materials-induced programmed cell death: A review of apoptosis, autophagy, and programmed necrosis. Int J Nanomedicine 12: 6633-6646, 2017.

13. Qian HR, Shi ZQ, Zhu HP, Gu LH, Wang XF and Yang Y: Interplay between apoptosis and autophagy in colorectal cancer. Oncotarget 8: 62759-62768, 2017.

14. Reczek CR and Chandel NS: ROS-dependent signal transduction. Curr Opin Cell Biol 33: 8-13, 2015.

15. Marchi S, Giorgi C, Suski JM, Agnoletto C, Bononi A, Bonora M, De Marchi E, Missiroli S, Patergnani S, Poletti F, et al: Mitochondria-ros crosstalk in the control of cell death and aging. J Signal Transduct 2012: 329635, 2012.

16. Na AR, Chung YM, Lee SB, Park SH, Lee MS and Yoo YD: A critical role for Romol-derived ROS in cell proliferation. Biochem Biophys Res Commun 369: 672-678, 2008.

17. Li L, Tan J, Miao Y, Lei P and Zhang Q: ROS and autophagy: Interactions and molecular regulatory mechanisms. Cell Mol Neurobiol 35: 615-621, 2015.

18. Scherz-Shouval R and Elazar Z: Regulation of autophagy by ROS: Physiology and pathology. Trends Biochem Sci 36: 30-38, 2011.

19. Xie J, Xu Y, Huang X, Chen Y, Fu J, Xi M and Wang L: Berberine-induced apoptosis in human breast cancer cells is mediated by reactive oxygen species generation and mitochondrial-related apoptotic pathway. Tumour Biol 36: 1279-1288, 2015.
20. Li GH, Lin XL, Zhang H, Li S, He XL, Zhang K, Peng J, Tang YL, Zeng JF, Zhao Y, et al: Ox-Lp(a) transiently induces HUVEC autophagy via an ROS-dependent PAPR-1-LKB1-AMPK-mTOR pathway. Atherosclerosis 243: 223-235, 2015.

21. Lee MS, Tsai CW, Wang CP, Chen JH and Lin HH: Anti-prostate cancer potential of gossypetin via inducing apoptotic and autophagic cell death. Mol Carcinog 56: 2578-2592, 2017.

22. Sun ZL, Dong JL and Wu J: Juglanin induces apoptosis and autophagy in human breast cancer progression via ROS/JNK promotion. Biomed Pharmacother 85: 303-312, 2017.

23. Sun D, Shen W, Zhang F and Fan H: Tan J1, Li L, Xu C, Zhang H, Yang Y, and Cheng $\mathrm{H}$ : $\alpha$-Hederin arrests cell cycle at $\mathrm{G} 2 / \mathrm{Mcheckpoint}$ and promotes mitochondrial apoptosis by blocking nuclear factor-B signaling in colon cancer cells. BioMed Res Int 2548378: 2018, 2018

24. Gumushan-Aktas H and Altun S: Effects of Hedera helix L. extracts on rat prostate cancer cell proliferation and motility. Oncol Lett 12: 2985-2991, 2016.

25. Claereboudt EJS, Eeckhaut I, Lins L and Deleu M: How different sterols contribute to saponin tolerant plasma membranes in sea cucumbers. Sci Rep 8: 10845, 2018.

26. Li J, Wu DD, Zhang JX, Wang J, Ma JJ, Hu X and Dong WG: Mitochondrial pathway mediated by reactive oxygen species involvement in $\alpha$-hederin-induced apoptosis in hepatocellular carcinoma cells. World J Gastroenterol 24: 1901-1910, 2018.

27. Lorent JH, Léonard C, Abouzi M, Akabi F, Quetin-Leclercq $\mathrm{J}$ and Mingeot-Leclercq MP: $\alpha$-Hederin induces apoptosis, membrane permeabilization and morphologic changes in two cancer cell lines through a cholesterol-dependent mechanism. Planta Med 82: 1532-1539, 2016

28. Sun D, Shen W, Zhang F, Fan H, Xu C, Li L, Tan J, Miao Y, Zhang , Yang Y, et al: $\alpha$-Hederin inhibits interleukin 6-induced epithelial-to-mesenchymal transition associated with disruption of JAK2/STAT3 signaling in colon cancer cells. Biomed Pharmacother 101: 107-114, 2018.

29. Sun J, Liu T and Xu J: Improving the anticancer activity of $\alpha$-hederin by physically encapsulating it with targeted micelles assembled from amphiphilic block copolymers. J Drug Deliv Sci Technol 35: 252-259, 2016.

30. Sun J, Xu K, Qiu Y, Gao H, Xu J, Tang Q and Yin P: Bufalin reverses acquired drug resistance by inhibiting stemness in colorectal cancer cells. Oncol Rep 38: 1420-1430, 2017.

31. Zhu R, Zhang CG, Liu Y, Yuan ZQ, Chen WL, Yang SD, Li JZ, Zhu WJ, Zhou XF, You BG, et al: CD147 monoclonal antibody mediated by chitosan nanoparticles loaded with $\alpha$-hederin enhances antineoplastic activity and cellular uptake in liver cancer cells. Sci Rep 5: 17904, 2015.

32. Cheng L, Xia TS, Wang YF, Zhou W, Liang XQ, Xue JQ, Shi L, Wang Y, Ding Q and Wang M: The anticancer effect and mechanism of $\alpha$-hederin on breast cancer cells. Int J Oncol 45: 757-763, 2014.

33. Cheng L, Xia TS, Wang YF, Zhou W, Liang XQ, Xue JQ, Shi L, Wang Y and Ding Q: The apoptotic effect of D Rhamnose $\beta$-hederin, a novel oleanane-type triterpenoid saponin on breast cancer cells. PLoS One 9: e90848, 2014.

34. Randhawa MA and Alghamdi MS: Anticancer activity of Nigella sativa (black seed) - a review. Am J Chin Med 39: 1075-1091, 2011.

35. Rooney S and Ryan MF: Effects of alpha-hederin and thymoquinone, constituents of Nigella sativa, on human cancer cell lines. Anticancer Res 25: 2199-2204, 2005.

36. Rooney S and Ryan MF: Modes of action of alpha-hederin and thymoquinone, active constituents of Nigella sativa, against HEp-2 cancer cells. Anticancer Res 25: 4255-4259, 2005.

37. Swamy SM and Huat BT: Intracellular glutathione depletion and reactive oxygen species generation are important in alphahederin-induced apoptosis of P388 cells. Mol Cell Biochem 245: 127-139, 2003.

38. Suen DF, Norris KL and Youle RJ: Mitochondrial dynamics and apoptosis. Genes Dev 22: 1577-1590, 2008.

39. Gump JM, Staskiewicz L, Morgan MJ, Bamberg A, Riches DW and Thorburn A: Autophagy variation within a cell population determines cell fate through selective degradation of Fap-1. Nat Cell Biol 16: 47-54, 2014

40. Dunlop EA and Tee AR: mTOR and autophagy: A dynamic relationship governed by nutrients and energy. Semin Cell Dev Biol 36: 121-129, 2014

41. Tanida I, Ueno T and Kominami E: LC3 and Autophagy. Methods Mol Biol 445: 77-88, 2008.

42. Kou B, Liu W, Xu X, Yang Y, Yi Q, Guo F, Li J, Zhou J and Kou Q: Autophagy induction enhances tetrandrine-induced apoptosis via the AMPK/mTOR pathway in human bladder cancer cells. Oncol Rep 38: 3137-3143, 2017. 
43. Zha QB, Zhang XY, Lin QR, Xu LH, Zhao GX, Pan H, Zhou D, Ouyang DY, Liu ZH and He XH: Cucurbitacin E induces autophagy via downregulating $\mathrm{mTORC} 1$ signaling and upregulating AMPK activity. PLoS One 10: e0124355, 2015.

44. Zhan Y, Wang K, Li Q, Zou Y, Chen B, Gong Q, Ho HI, Yin T, Zhang F, Lu Y, et al: The novel autophagy inhibitor alpha-hederin promoted paclitaxel cytotoxicity by increasing reactive oxygen species accumulation in non-small cell lung cancer cells. Int J Mol Sci 19: 3221, 2018.

45. Wu AG, Zeng W, Wong VK, Zhu YZ, Lo AC, Liu L and Law BY: Hederagenin and $\alpha$-hederin promote degradation of proteins in neurodegenerative diseases and improve motor deficits in MPTP-mice. Pharmacol Res 115: 25-44, 2017.

46. Roach PJ: AMPK -> ULK1 -> autophagy. Mol Cell Biol 31: 3082-3084, 2011.

47. Mao X, Yu CR, Li WH and Li WX: Induction of apoptosis by shikonin through a ROS/JNK-mediated process in Bcr/Abl-positive chronic myelogenous leukemia (CML) cells Cell Res 18: 879-888, 2008.

48. Ghavami S, Eshragi M, Ande SR, Chazin WJ, Klonisch T, Halayko AJ, McNeill KD, Hashemi M, Kerkhoff C and Los M: S100A8/A9 induces autophagy and apoptosis via ROS-mediated cross-talk between mitochondria and lysosomes that involves BNIP3. Cell Res 20: 314-331, 2010.

49. Chen S, Rehman SK, Zhang W, Wen A, Yao L and Zhang J: Autophagy is a therapeutic target in anticancer drug resistance. Biochim Biophys Acta 1806: 220-229, 2010.

50. Xu L, Qu XJ, Liu YP, Xu YY, Liu J, Hou KZ and Zhang Y: Protective autophagy antagonizes oxaliplatin-induced apoptosis in gastric cancer cells. Chin J Cancer 30: 490-496, 2011.

51. Wang N, Feng Y,Zhu M, Tsang CM, Man K, Tong Y and Tsao SW: Berberine induces autophagic cell death and mitochondrial apoptosis in liver cancer cells: The cellular mechanism. J Cell Biochem 111: 1426-1436, 2010

52. Kanzawa T, Zhang L, Xiao L, Germano IM, Kondo Y and Kondo S: Arsenic trioxide induces autophagic cell death in malignant glioma cells by upregulation of mitochondrial cell death protein BNIP3. Oncogene 24: 980-991, 2005.
53. Zhai B, Hu F, Jiang X, Xu J, Zhao D, Liu B, Pan S, Dong X, Tan G, Wei Z, et al: Inhibition of Akt reverses the acquired resistance to sorafenib by switching protective autophagy to autophagic cell death in hepatocellular carcinoma. Mol Cancer Ther 13: 1589-1598, 2014.

54. Bang SC, Seo HH, Shin HR, Lee KC, Hoang TA and Jung SH: A convenient preparation of a disaccharide motif and its role in the cytotoxicity of the triterpenoid saponin, alpha-hederin. Arch Pharm Res 31: 555-561, 2008.

55. Jeong HG and Park HY: The prevention of carbon tetrachloride-induced hepatotoxicity in mice by alpha-hederin: Inhibiton of cytochrome P450 2E1 expression. Biochem Mol Biol Int 45: 163-170, 1998.

56. Gaillard Y, Blaise P, Darré A, Barbier T and Pépin G: An unusual case of death: Suffocation caused by leaves of common ivy (Hedera helix). Detection of hederacoside $\mathrm{C}, \alpha$-hederin, and hederagenin by LC-EI/MS-MS. J Anal Toxicol 27: 257-262, 2003.

57. Delmas F, Di Giorgio C, Elias R, Gasquet M, Azas N, Mshvildadze V, Dekanosidze G, Kemertelidze E and Timon-David P: Antileishmanial activity of three saponins isolated from ivy, alpha-hederin, beta-hederin and hederacolchiside A1, as compared to their action on mammalian cells cultured in vitro. Planta Med 66: 343-347, 2000.

58. Danloy S, Quetin-Leclercq J, Coucke P, De Pauw-Gillet MC, Elias R, Balansard G, Angenot L and Bassleer R: Effects of alpha-hederin, a saponin extracted from Hedera helix, on cells cultured in vitro. Planta Med 60: 45-49, 1994.

59. Takechi M and Yasuo T: Structure-activity relationships of the saponin $\alpha$-hederin. Phytochemistry 29: 451-452, 1990.

This work is licensed under a Creative Commons Attribution-NonCommercial-NoDerivatives 4.0 International (CC BY-NC-ND 4.0) License. 